\title{
An integrated geodetic and InSAR technique for the monitoring and detection of active faulting in southwestern Sicily
}

\author{
Giovanni Barreca ${ }^{3}$, Valentina Bruno ${ }^{1}$, Gino Dardanelli ${ }^{1}$, Francesco Guglielmino ${ }^{1}$, \\ Mauro Lo Brutto ${ }^{2}$, Mario Mattia*,1, Claudia Pipitone ${ }^{1}$ and Massimo Rossi ${ }^{1}$ \\ (1) Istituto Nazionale di Geofisica e Vulcanologia, Osservatorio Etneo, Piazza Roma 2, 95123 Catania, Italy \\ (2) Università degli Studi di Palermo, Dipartimento di Ingegneria, Palermo, Italy \\ (3) Università degli Studi di Catania, Dipartimento di Scienze Geologiche, Biologiche ed Ambientali, Catania, Italy
}

Article history: received July 31, 2019; accepted September 3, 2019

\begin{abstract}
We present the results of the analysis of GNSS (Global Navigation Satellite System) and InSAR (Interferometric synthetic-aperture radar) data collected in the frame of a project financed by the "Struttura Terremoti" of INGV (Istituto Nazionale di Geofisica e Vulcanologia). Combined investigations pointed out for potential seismogenic sources for destructive earthquakes recorded in southwestern Sicily, including the 1968 Belice earthquake sequence and that supposed to have destroyed the Greek city of Selinunte which, according to geoarcheological data experienced two earthquakes in historical times. Our approach is aimed to evaluate the current deformation rate in SW Sicily and to improve the knowledge about the seismic potential of this area. The geodetic data proposed in this paper show that the Campobello di Mazara-Castelvetrano alignment (CCA) is currently deforming with a vertical and horizontal displacements of $2 \mathrm{~mm} / \mathrm{yr}$ and $0.5 \mathrm{~mm} / \mathrm{yr}$ respectively, according to the tectonic setting of the area.
\end{abstract}

Keywords: Belice earthquake; GNSS data; InSar data: Geodesy.

\section{Introduction}

Although the investigated area has been occasionally hit by strong earthquakes both in recent and historical time [e.g. Belice, 1968 and Selinunte events CPTI11, Rovida et al., 2011, Guidoboni et al., 2002; Bottari et al., 2009], data about the pattern of active deformation are scarce and/or poorly constrained. This is mainly related to the low rate of deformation affecting the southwestern Sicily, which doesn't allow to the shaping of prominent morpho-structural expressions of possible active tectonic structures. Even if both historical and instrumental records reveal that the seismicity of southwestern Sicily is characterized by sparse, low-moderate magnitude earthquakes [ISIDE database; http://iside.rm.ingv.it/iside/standard/index.jsp; see also Rigano et al., 1999; Rovida et al., 2011], the occurrence of strong earthquakes in the past suggest instead the investigated area as having a high seismic potential. However, exhaustive information on the location, kinematics and dimensions 


\section{Giovanni Barreca et al.}

of the active tectonic structures responsible for large earthquakes in the area are still lacking and/or their rate of deformation is not fully understood. This uncertainty reflects in official databases, such as DISS, where the proposals on seismogenic sources capable of generating earthquakes with $\mathrm{M}>5.5$ are preliminary and based on the few data available in the literature [Diss Working Group, 2010]. Geodetic observations, very useful to clarify the nature of deformation on a regional scale [Ferranti et al., 2008; Devoti et al., 2011; Palano et al., 2012], have also been able to provide constraints on the position and nature of the active structures in SW sector of Sicily [Barreca et al., 2014].

With the aim to investigate the dynamics of tectonics occurring in in SW Sicily and to understand how stress is dissipated through time, a new set of GNSS data has been collected by using both permanent and episodically surveyed stations, respectively. Further, we performed the SENTINEL 1A-1B Advanced DInSAR analysis covering the 2014-2018 time span to investigate the short-term dynamics of the active faults deforming the investigated area. More specifically, we focused on the sector in-between Campobello and Castelvetrano localities, where an active fault segment was already identified by previous authors [see Barreca et al. 2014].

Results, lastly framed in the larger geodynamic contest of Sicily, confirm the meaningful deformation rate across the Campobello di Mazara-Castelvetrano active structure and permits new insights for the evaluation of its seismic potential in the light of the earthquakes occurred in the past.

\section{Background}

\subsection{Geological setting}

The investigated area in SW Sicily represents the westernmost part of the Sicilian Fold and Thrust Belt (hereafter, SFTB, Figure 1A), a south-verging contractional belt segment of the wider Appennine-Maghrebian orogenic system, the suture zone between the colliding Africa and European plates [Dewey et al., 1989; Ben Avraham et al., 1990]. The SFTB is the result of the Neogene-Quaternary tectonic processes during which a preorogenic configuration (formed at that time by both platform and open-shelf rock series, i.e. the African continental paleo-margin) has been progressively shortened to form a wide thrusting system. The westernmost segment of the SFTB (i.e. the studied area), consists of NE-SW trending structural domains composed of several, thrust-bounded, foreland-verging tectonic blocks (Figure 1B) at present interposed between two extensional domains, the Tyrrhenian Basin to the north and the stretched Sicily channel region to the south (Figure 1A). Deep seismic explorations in the area [Catalano et al 1998, 2000], revealed the structural architecture of SW Sicily as formed by two overlapping thrust wedges separated by a regional decollement. In this duplex-shaped deformation context, the upper structural layer consists of a thin (1-3Km thick), smallwavelength fold and thrust system while the lower is given by a thicker $(\sim 10 \mathrm{~km})$ thrust stack [Catalano et al., 2000] resulting by the deepening of thrust contacts in response to the Late Miocene-Early Pliocene collisional processes [Bello et al., 2000, Catalano et al., 2000; Avellone et al., 2010; Barreca et al., 2010; Barreca and Maesano, 2012]. The propagation of the younger, deep-seated thrusting re-deformed the previously stacked tectonic units (e.g. the overlain thrust wedge - middle Miocene) and was accompanied by the development of large marine basins at the footwall of major contractional structures. This later process and the resulting tectonic structures are considered to be still active and have been retained to be responsible for the nucleation of large earthquakes in the area [e.g. the 1968 Belice seismic crisis, see Monaco et al., 1996, Lavecchia et al., 2007; Barreca et al., 2014]. Accordingly, the seismotectonic processes that involve this region appears to be related to ongoing compressional activity along deep-seated, high-angle thrust contacts that, at a shallower crustal level, display flat-ramps geometries of deformation. Clues for a recent tectonic activity came only from slightly folded Holocene lacustrine deposits in the frontal part of the tectonic stack [Monaco et al., 1996 and reference therein] and from faulted archaeological remains [Barreca et al., 2014]. However, the clayey lithology occurring in the area and the low rate of deformation make difficult the identification of surface expression of active faults, being the latter rapidly modelled by erosive processes. 


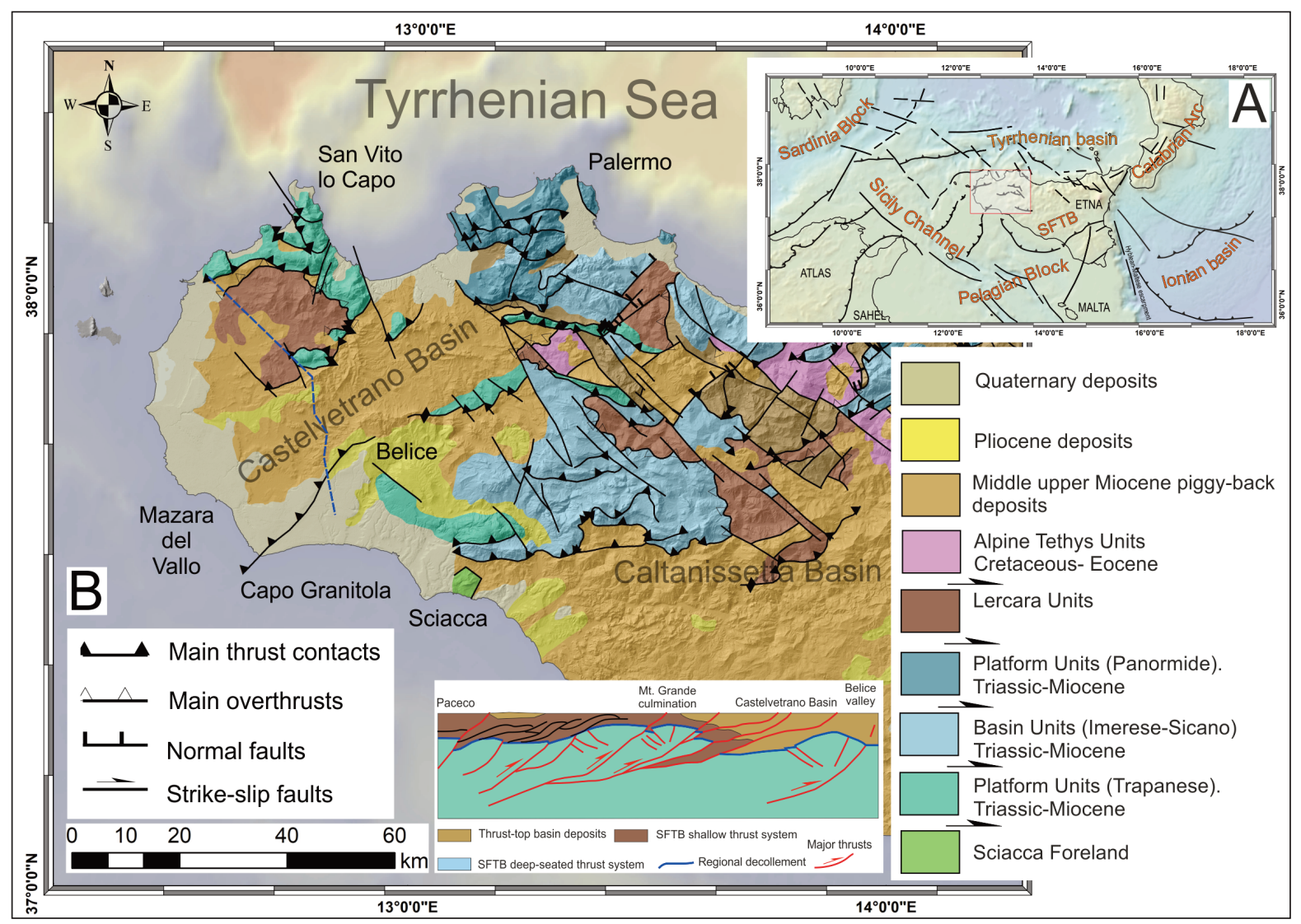

Figure 1. a) Tectonic model of the Central Mediterranean region where SFTB occur. Lines represent the main faults. Lines with triangles represent the main contractional tectonic features. (b) Geological sketch map of central-western Sicily (from Finetti et al., 2005, modified) showing the main tectonic units and contacts, the latter consisting mostly of thrust and strike-slip faults.

\subsection{Seismotectonic}

Apart from the Palermo (1726, 1734, 1940, 2002) and Belice (1968) destructive earthquakes, historical and instrumental records [Boschi et al., 2000; Gruppo di Lavoro CPTI, 2004; Pondrelli et al., 2006; Guidoboni et al., 1994] reveals that the seismicity of western Sicily is characterised by only a few moderate magnitude earthquakes with epicentres spread from the Tyrrhenian coast to the and Sicily Channel. In fact, before the 1968 Belice seismic sequence, the most significant seismic event occurred in the area after the Roman colonization, the westernmost segment of the SFTB was considered a rather seismically quiescent region. Further, archaeological evidences analyzed in the last decade [e.g. Guidoboni et al., 2002; Bottari et al., 2009] suggest also the occurrence in the area of two ancient and strong earthquakes (between 370 and 300 B.C. and between 300 and 600 A.D.) that destroyed the Greek colony of Selinunte in the South-west coast of Sicily (see Figure 2 for location). The 1968 seismic swarm nucleated at shallow to middle crustal domain with focal depths ranging from 1 to $39 \mathrm{~km}$ [Anderson and Jackson,1987] while epicenters (Figure 2) distributed over a large part of south-western Sicily [De Panfilis and Marcelli 1968, Marcelli and Pannocchia, 1971; Bottari, 1973, Anderson and Jackson,1987] including the Tyrrhenian coast (to the north) and the Sciacca off-shore (to the south). Most of seismic events localized within the NE-SW trending Castelvetrano structural depression (Figure 1B) where a number of events clustered around the Belice River valley with a main gathering in the nearby of Poggioreale, Salaparuta and Gibellina villages (Figure 2).

According to the focal solutions proposed in the literature (mainly coming from the Belice 1968 seismic sequence, see Figure 2), the seismotectonic processes in the area are governed by a nearly $\mathrm{N}-\mathrm{S}$ trending $\mathrm{P}$-axis, compatible with a right-lateral component of motion along NNW-striking planes or, alternatively, with thrusting 


\section{Giovanni Barreca et al.}

mechanisms along ENE-trending planes [Anderson and Jackson, 1987]. An almost pure reverse mechanism with a nearly N-S trending P-axis is also provided by the Mazara 1981 earthquake $(\mathrm{Mw}=4.9)$, located about $30 \mathrm{~km}$ to the west of the Belice area [Pondrelli et al., 2006; Lavecchia et al., 2007, see Figure 2 for location].

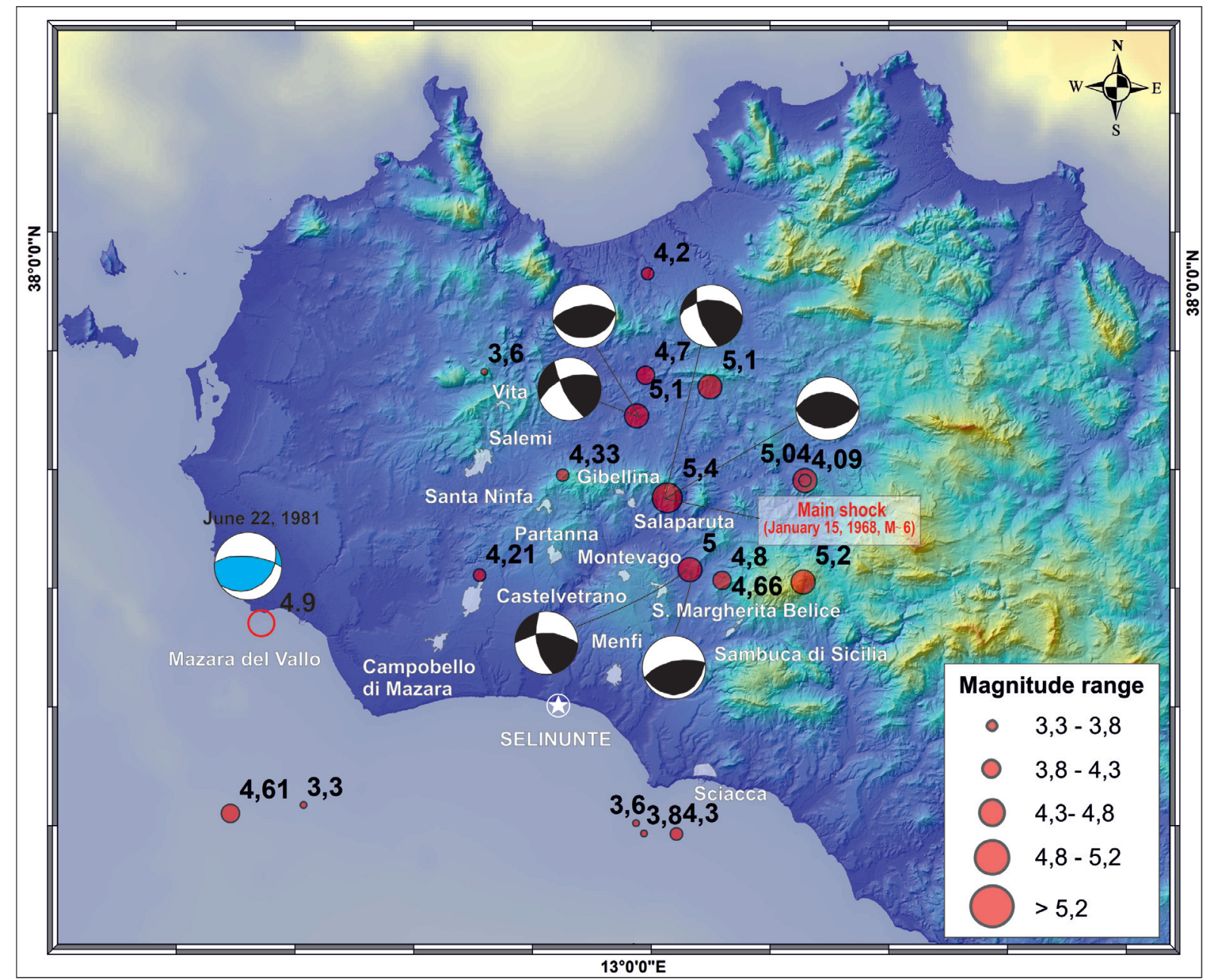

Figure 2. Seismic events distribution, magnitude and focal solution of the 1968 earthquake sequence (from Anderson and Jackson, 1987). Focal solutions show either right-lateral strike-slip or thrust focal mechanisms. Light blue focal mechanism is that of the 1981 Mazara earthquake (from Pondrelli et al.,2006).

\subsection{The 1968 Belice seismic sequence}

At 2.01.04 (GMT) of January 15, 1968, a wide area of western Sicily was hit by a strong [M 6, De Panfilis and Marcelli 1968; Anderson and Jackson,1987] earthquake, the main shock of a high frequency seismic swarm (more than 300 events) that shaken the region for about a month later (from 14th to 25th January 1968). The disastrous event, the strongest seismic event recorded in Western Sicily in historical time, was preceded by a series of minor events (on January 14 with $4.7<M<4.9$ ) and followed by several aftershocks among these the events of 16 and 25 January reached the magnitude of 5.7 [De Panfilis and Marcelli 1968; Bottari, 1973; Anderson and Jackson,1987]. The seismic event caused about 370 deaths and severe damaging on fourteen villages facing the Belice river valley. Four of these (Gibellina, Poggioreale, Salaparuta and Montevago) were completely destroyed. Ground effects related to 1968 earthquakes were generally scarce and occurred mainly at the northern limb of Belice syncline and consisted of moderate landslides, mud upraise along fractures and fluids escape [see Michetti et al., 1995; Bosi et al., 1973]. Sand blows and fissures related to liquefactions phenomena was observed along the Belice alluvial river plain [Haas and Ayre, 1969] 


\section{Data and methods}

\subsection{InSAR data}

In order to detect the ground deformation in western Sicily, we performed a Differential Interferometry Synthetic Aperture Radar (DInSAR) analysis of C-band Sentinel-1A data referring to 2015 May 2017 and 2019 July 09. The two Sentinel-1 images were acquired in TopSAR Interferometric Wide (IW) mode (VV polarisation) along the 117 ascending orbit. The SentinelA data were processed by GAMMA software, using a spectral diversity method and a procedure able to co-register the SENTINEL pairs with extremely high precision (< 0.01 pixel). The 4 years' time spanning interferogram was produced by applying a two-pass DInSAR processing (using the GAMMA software), and we applied a multilook $5 \times 1$ (range and azimuth) in order to maintain the full ground resolution $(11 \times 13 \mathrm{~m})$ and to remove the topographic phase from interferogram the SRTM V4 Digital Elevation Model (DEM) generated by Shuttle Radar Topography Mission (SRTM) with 3 arc-second resolution (about 90 m) was used [Jarvis et al., 2008].

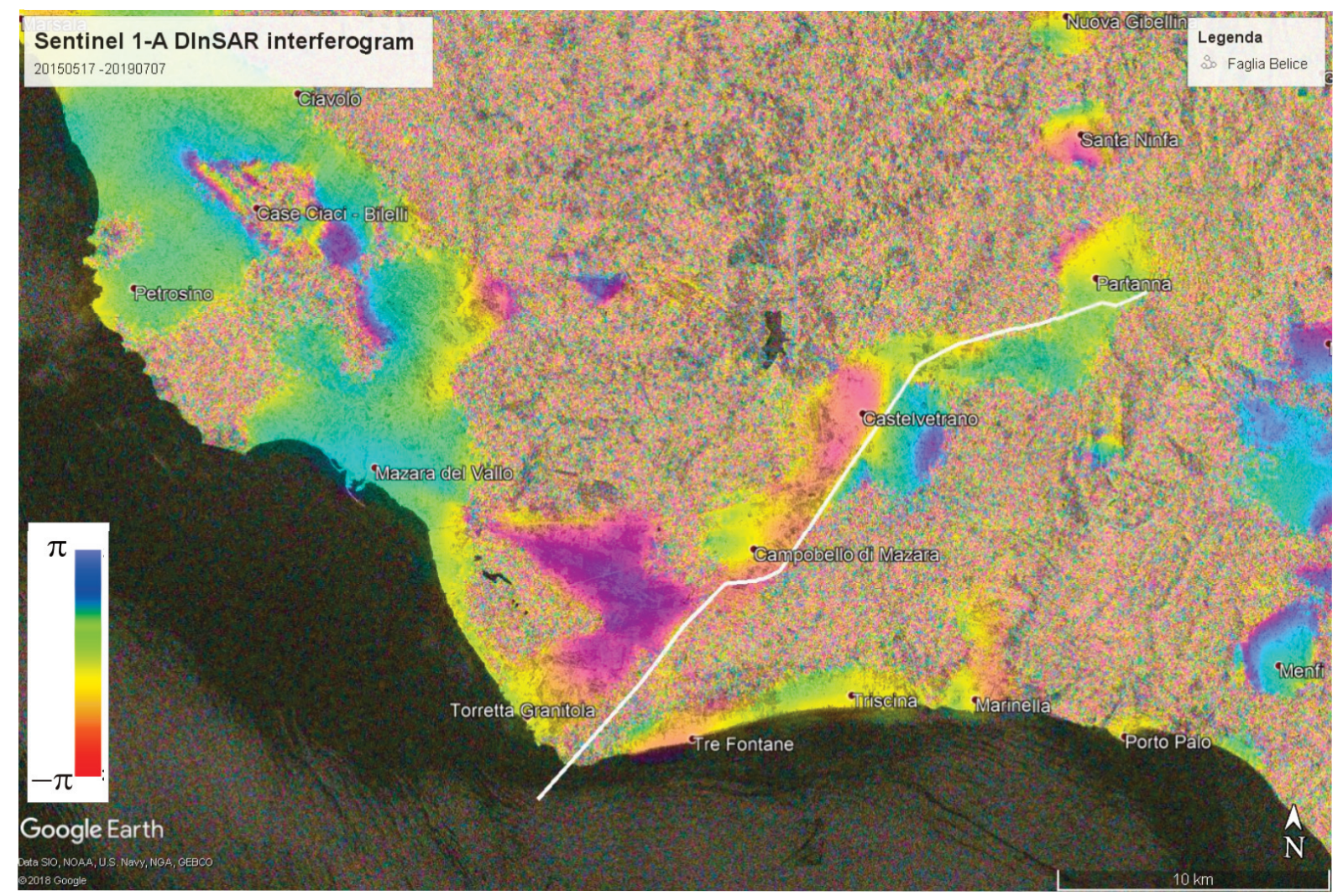

Figure 3. InSAR interferogram of SW Sicily spanning the period 2015 May 2017 and 2019 July 09.

\subsection{GNSS data}

In 1992 the Italian IGM (Istituto Geografico Militare - www.igmi.org) started the GPS measuring of a network made up of 1260 benchmarks, about $20 \mathrm{~km}$ far from each other and extended over the whole Italy. We have reoccupied five IGM benchmarks in South-western Sicily in order to calculate the surface velocity map and to obtain independent information on strain rate accumulation on the Castelvetrano-Campobello alignment revealed by interferometric data. Every single session of data acquisition span 4-5 h for the first IGM campaign in 1994 and 5$13 \mathrm{~h}$ for the 2013 and 2016 surveys.

In order to improve the quality and the density of our results, we also used a set of data from the network managed by the University of Palermo (black dots, Figure 4), spanning the period 2008-2016. Indeed, since 2007, the 


\section{Giovanni Barreca et al.}

University of Palermo developed a relevant project to guarantee the presence of several permanent station at Palermo, Trapani, Agrigento and Caltanissetta. After the CORS (Continuous Operating Reference Stations) installation, in the last years, several tests have been carried out for technical and scientific purposes, aiming to perform experimental research for GNSS positioning, topographic and cartographic activities and earthquake supporting. In particular, the analyses focused on the comparison between in situ conventional geodetic and GNSS measurements, by using total station and digital level [Dardanelli and Pipitone, 2017], or the comparison between GNSS results and real-time corrections via Networked Transport of RTCM via Internet Protocol (NTRIP) protocol for Mobile Mapping System (MMS) applications (Dardanelli et al. 2015). In the last few years, many other studies involved the use of UNIPA CORS network, and recently, the results from GNSS have been integrated to remote sensing applications [Dardanelli et al. 2014, Pipitone et al. 2018]

Figure 4. Distributed UNIPA CORS network.

The CORS GNSS network for real time and post-processing monitoring managed by the University of Palermo consists of nine CORS far away from each other from 22 to 80 kilometres. The reference stations are equipped with Topcon NET-G3 GPS and GLONASS receivers and TPSCR3_GGD with CONE antennas. The Topcon software TopNET was used for real-time network corrections and Receiver Independent Exchange Format (RINEX) data. Recently, three reference stations from Palermo (PALE), Campobello di Mazara (CAMP), Termini Imerese (TERM) have been included and computed in the Italian GPS dynamic permanent network called Rete Dinamica Nazionale (RDN, http://www.igmi.org/rdn ).

We processed the GPS data using the GAMIT/GLOBK software [Herring et al., 2018; Herring et al., 2015] with IGS (International GNSS Service) precise ephemerides. We tied the measurements to an external global reference frame by including in our analysis the data from CGPS stations belonging to the IGS and EURA networks, many of which operating since 1994. The loosely constrained daily solutions were then transformed into ITRF2008 [Altamimi et al., 2011] and then rotated to obtain the velocity field into a fixed Europe reference frame. Furthermore, the velocity solutions have been inverted to derive continuous horizontal velocity and strain rate fields in western Sicily. We have applied the method described by Haines and Holt [1993], improved by Holt and Haines [1995] and later used also in 
other papers [Haines et al., 1998; Kreemer et al., 2000]. Besides plates boundary zones [Kreemer et 2000; Beavan and Haines, 2001] this method has been applied also to seismogenic areas both on a regional and local scale [Mattia et al., 2009, 2012; Barreca et al., 2014] and to volcanic areas [Bruno et al., 2012]. See Bruno et al. [2012] for more details on the methodology.

\begin{tabular}{|c|c|c|c|c|c|c|}
\hline Site & Long. (deg) & Lat. (deg) & Ve (mm/yr) & Vn (mm/yr) & Se $(\mathrm{mm} / \mathrm{yr})$ & $\mathrm{Sn}(\mathrm{mm} / \mathrm{yr})$ \\
\hline AGRG & 13.601 & 37.320 & -2.42 & 2.64 & 0.92 & 0.91 \\
\hline ALCM & 12.956 & 37.974 & -1.11 & 3.06 & 1.23 & 1.22 \\
\hline BCMA & 12.766 & 37.648 & -0.84 & 2.93 & 1.57 & 1.52 \\
\hline CAMP & 12.745 & 37.629 & -1.20 & 2.55 & 0.91 & 0.90 \\
\hline FGR2 & 12.662 & 37.567 & -1.51 & 2.80 & 1.47 & 1.27 \\
\hline MGAI & 13.193 & 37.864 & -0.45 & 3.78 & 1.54 & 1.49 \\
\hline MGRA & 12.762 & 37.895 & -0.88 & 2.48 & 1.55 & 1.47 \\
\hline PART & 13.110 & 38.040 & -1.33 & 3.96 & 1.29 & 1.28 \\
\hline PAUN & 13.348 & 38.106 & -1.07 & 4.70 & 1.52 & 1.50 \\
\hline PRIZ & 13.437 & 37.719 & -0.90 & 3.00 & 1.31 & 1.28 \\
\hline SEL1 & 12.836 & 37.587 & -1.73 & 2.60 & 1.52 & 1.50 \\
\hline SETA & 14.042 & 37.486 & -0.53 & 2.05 & 1.50 & 1.49 \\
\hline TERM & 13.702 & 37.983 & -1.18 & 3.76 & 0.97 & 0.96 \\
\hline TLIP & 12.716 & 37.745 & -2.03 & 2.06 & 1.47 & 1.45 \\
\hline TRAP & 12.541 & 38.013 & -0.86 & 2.54 & 1.48 & 1.45 \\
\hline
\end{tabular}

Table 1. Site code, geodetic coordinates, East and North velocity components and associated errors for all benchmarks.

\section{Results}

Inspection of the InSAR Line Of Sight (LOS) ground deformation confirmed the displacement rate reported in Barreca et al. (2014), with the evidence of two areas characterized by differential ground motion: (i) the first area trends NW-SE and is located between the towns of Marsala and Mazara del Vallo, probably due to intensive water pumping for agricolture; (ii) the second area with a roughly SSW-NNE orientation, corresponding to Campobello di Mazara-Castelvetrano alignment (CCA), is characterized by about $7 \mathrm{~mm}$ of differential ground motion.

The horizontal velocity field in the Eurasian fixed reference frame shows that the GNSS stations of western Sicily move with velocities ranging from about 2.1 to $4.8 \mathrm{~mm} / \mathrm{yr}$ along NNW to NW directions. The magnitude of the horizontal velocities decreases from almost $5 \mathrm{~mm} / \mathrm{yr}$ along the Northern coastline to the mean value of $2.9 \mathrm{~mm} / \mathrm{yr}$ along the most western sector of the investigated area and along the CCA alignment. Furthermore, the velocity values slightly decrease across the CCA alignment, from East to West, from about $3.2 \mathrm{~mm} / \mathrm{yr}$ (SEL1) to values of 2.8 $\mathrm{mm} / \mathrm{yr}$ (CAMP). The decrease in magnitude of velocity is accompanied by minor azimuth variations. The different velocities affecting the stations lying on the different sides of the CCA alignment, although small, are in agreement with the field evidences of active deformation found by Barreca et al. [2014].

We have also inverted the GPS velocities to obtain the shear strain rate distribution. The regions with higher strain concentration are often locations of seismogenic faults and more prone to be the source of future earthquakes, releasing elastic energy accumulated in the neighbourhood over the interseismic time period. Figure 5 shows that the shear strain rate in western Sicily is mainly distributed along a SW-NE direction that corresponds to the area of the CCA alignment. It reaches maximum values of about $12 \cdot 10^{-16} \mathrm{1} / \mathrm{s}$. Geodetically observed strain rate has some limitations due to the fact that it includes both elastic and anelastic strains, and in many cases, it is difficult to differentiate the two components without a priori knowledge. Because only the elastic strain is responsible for earthquakes, try to understand where seismic energy could be released, using geodetic strain, alone is not an 


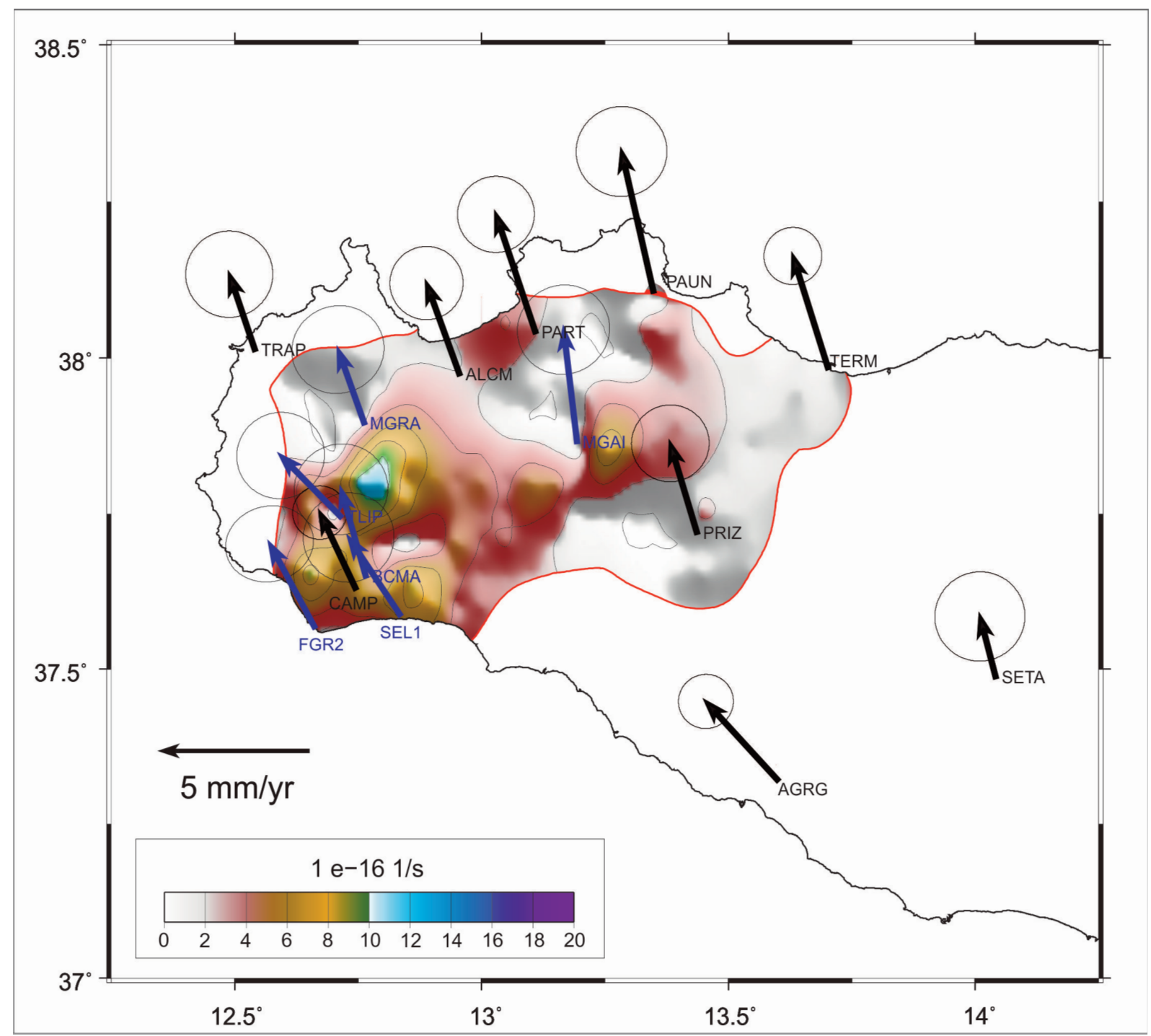

Figure 5. Horizontal GPS velocities with 95\% confidence ellipses in the Eurasian reference frame for the measured IGM benchmarks (1994-2016) (blue arrows) and permanent GPS stations (black arrows) in western Sicily. The magnitude of geodetic shear strain rate is reported as colour map, enclosed by the red line, that indicate $50 \%$ resolution level of the map (Kreemer et al., 2000).

exhaustive approach, particularly across faults that are creeping or in regions where significant amounts of deformation take place plastically. Although geological observations have indicated that stress along the CCA alignment is at present released as aseismic creep [Barreca et al., 2014], coseismic ruptures could propagate up to the earth surface, as probably occurred in the past [Barreca et al., 2014], considering that the area is spatially coincident with the macroseismic zone of the1968 Belice earthquake.

\section{Conclusions}

According to measured GPS benchmarks, western Sicily move with velocities ranging from about 2.1 to $4.8 \mathrm{~mm} / \mathrm{yr}$ along NNW to NW directions, suggesting an intraplate differential geodetic velocity of about $3 \mathrm{~mm} / \mathrm{a}$. Strain rate derived map, decrease of velocity values, and ground deformation rates from the interferometric methods clearly indicate that most of strain is accumulating in SW Sicily and particularly along the CCA alignment, were archaeological remains were displaced by a reverse fault [see Barreca et al., 2014]. Maximum of strain rate (see 
Figure 5) and differential ground motion (Figure 4) depict in fact an NNE-SSW trending boundary that well match with the previously mapped CCA tectonic alignment. Here, the deformation rate is clearly defined by the vertical and horizontal displacements of $2 \mathrm{~mm} / \mathrm{a}$ and $0.5 \mathrm{~mm} / \mathrm{a}$ respectively, which, according to the tectonic setting of the area (see section 2.1), are compatible with a high angle thrust fault displacing, as expected, mainly along the vertical component rather than the horizontal one. New data permit thus to refine better the previously performed geodetic and satellite measurements [see Barreca et al., 2014] and to evaluate the short-term (last five years) deformation rate in the Belice area. Obtained values indicate that the rate of deformation has remained constant during the analysed time span and confirms the low rate of horizontal deformation in the analysed sector, which seems also to suggest a long recurrence time for large earthquakes. Since no significant earthquakes have occurred after the Belice 1968 event, measured deformations seem to suggest that most of stress could be dissipate via aseismic creeping mainly along the CCA alignment. This could be due to a possible diffraction into discrete splays of major deep-seated thrust contacts at shallow crustal level. Splays mainly propagate aseismically within the clayey lithologies characterizing the upper level of the duplex system (see section 2.1). Alternatively, considering the rigidity of carbonates forming the main deep-seated tectonic blocks, the measured strain and the aseismic behaviour of CCA could be interpreted as the (short) non-elastic stage of deformation preceding rupture in the area.

To conclude, the combined technique here proposed, when accompanied by field studies, revealed a powerful tool in seismotectonic analysis since it allows monitoring and detecting of active faults even in slowly deforming area such as the one here analysed.

Acknowledgements. Copernicus Sentinel-1 data (2015-2019) are provided by ESA in the framework of GEO-GSNL initiative and available at the Copernicus Open Access Hub (https://scihub.copernicus.eu).

\section{References}

Altamimi, Z., X. Collilieux and L. Metivier (2011). ITRF2008: an improved solution of the International Terrestrial Reference Frame, J. Geod., 85(8):457-473, doi:10.1007/s00190-011-0444-4.

Anderson, H., and J. Jackson (1987). Active tectonics of the Adriatic Region. Geophys. J.R. Astr. Soc., 91, 937-983.

Avellone, G., M.R. Barchi, R. Catalano, M.G. Morticelli and A. Sulli (2010). Interference between shallow and deepseated structures in the Sicilian fold and thrust belt, Italy. J. Geol. Soc., 167, 109-126, doi:10.1144/0016-76492008-163.

Barreca, G., and F.E. Maesano (2012). Restraining stepover deformation superimposed on a previous fold-and thrustbelt: A case study from the Mt. Kumeta-Rocca Busambra ridges (western Sicily,Italy), J. Geodyn., 55, 1-17, doi:10.1016/j.jog.2011.10.007

Barreca, G., F.E Maesano and S. Carbone (2010). Tectonic evolution of the Northern Sicanian-Southern Palermo Mountains range in Western Sicily: insight on the exhumation of the thrust-involved foreland domains. It. J. Geosci., 129 (3), 234-247.

Barreca, G., V. Bruno, C. Cocorullo, F. Cultrera, L. Ferranti, F. Guglielmino, L. Guzzetta, M. Mattia, C. Monaco and F. Pepe (2014). Geodetic and geological evidence of active tectonics in south-western Sicily (Italy), J. Geod., 82, 138-149, doi:10.1016/j.jog.2014.03.004.

Beavan, J. and J. Haines (2001). Contemporary horizontal velocity and strain rate fields of the Pacific-Australian plate boundary zone through New Zealand, J. Geophys. Res., 106, 741-770, doi:10.1029/2000JB900302.

Bello, M., A. Franchino, and S. Merlini (2000). Structural model of eastern Sicily. Memorie della Società Geologica Italiana 55, 61-70.

Ben-Avraham, Z., M. Boccaletti, G. Cello, M. Grasso, F. Lentini, L. Torelli and L. Tortorici (1990). Principali domini strutturali originatisi dalla collisione neogenico-quaternaria nel Mediterraneo centrale: Memorie della Società Geologica Italiana, v. 45, 453-462.

Bosi, C., R. Cavallo and V. Francaviglia (1973). Aspetti geologici e geologico-tecnici del terremoto della Valle del Belice del 1968. Mem. Soc. Geol. It., 12, 81-130.

Bottari, A. (1973). Attività sismica e neotettonica della Valle del Belice. Ann. Geof., XXVI (1), 55-83.

Bottari, C., S.C. Stiros and A. Teramo (2009). Archaeological evidence for destructive earthquakes in Sicily between 


\section{Giovanni Barreca et al.}

400 B.C. and A.D. 600, Geoarchaeology, 24 (2),147-175, http://dx.doi.org/10.1002/gea.20260.

Bruno, V., M. Mattia, M. Aloisi, M. Palano, F. Cannavò and W. E. Holt (2012). Ground deformations and volcanic processes as imaged by CGPS data at Mt. Etna (Italy) between 2003 and 2008, J. Geophys. Res., 117, B07208, doi:10.1029/2011JB009114.

Catalano, R., B. D’Argenio and L. Torelli (1989). A geological section from Sardinia Channel to Sicily Straits based on seismic and field data. In: Boriani, A.B., Piccardo, M., Vai, G.B (Eds.), The lithosphere in Italy: Advances in Earth Science Research. Atti dei Convegni Lincei, vol. 80. Italian National Commitee for the International Lithosphere Program, pp. 110-128.

Catalano, R., A. Franchino, S. Merlini and A. Sulli (2000). Central western Sicily structural setting interpreted from seismic reflection profiles. Memorie della Società Geologica Italiana 55, 5-16.

Dardanelli, G., G. La Loggia, N. Perfetti, F. Capodici, L. Puccio and A. Maltese (2014). Monitoring displacements of an earthen dam using GNSS and remote sensing, in Proc. SPIE 9239, Remote Sensing for Agriculture, Ecosystems, and Hydrology XVI, Amsterdam, Netherlands, 923-928.

Dardanelli, G., S. Paliaga, M. Allegra, M. Carella and V. Giammarresi (2015). Geomatic applications to urban park in Palermo, Geographia Technica, 10(1), 28-43.

Dardanelli, G. and C. Pipitone (2017). Hydraulic models and finite elements for monitoring of an earth dam, by using GNSS techniques, Period. Polytech. Civil Eng., 61(3), 421-433.

De Panfilis, M., and L. Marcelli (1968). Il periodo sismico della Sicilia occidentale iniziato il 14 gennaio 1968, Ann. Geof., XXI, 4, 343-420.

Devoti, R., A. Esposito, G. Pietrantonio, A.R. Pisani and F. Riguzzi (2011). Evidence of large scale deformation patterns from GPS data in the Italian subduction boundary, Earth Planet. Sci. Lett., 311, 230-241, doi:10.1016/j.epsl.2011.09.034.

Dewey, J.F., M.L Helman, E. Turco, D.H.W, Hutton and S.D Knott (1989). Kinematics of the Western Mediterranean, in Coward, M.P., Dietrich, D., and Park, R.G., eds., Alpine Tectonics: Geological Society of London Special Publication 45, 265-283.

DISS Working Group, 2010. http://diss.rm.ingv.it/diss/, @ INGV 2010.

Ferranti, L., J.S Oldow, B. D’Argenio, R. Catalano, D. Lewis, E. Marsella, G. Avellone, L. Maschio, G., F. Pappone, F. Pepe and A. Sulli (2008). Active deformation in Southern Italy, Sicily and southern Sardinia from GPS velocities of the Peri-Tyrrhenian Geodetic Array (PTGA), Ital. J. Geosci. 127 (2), 299-316.

Guidoboni, E., A. Comastri and G. Traina (1994). Catalogue of Ancient Earthquakes in the Mediterranean Area up to the 10th Century: Bologna, ING, $504 \mathrm{p}$.

Guidoboni, E., A. Muggia, C. Marconi and E. Boschi (2002). A case study in archaeo-seismology. The collapses of the Selinunte Temples (Southwestern Sicily): two earthquakes identified, Bull. Seismol. Soc. Am. 92, 2961-2982.

Haas, J.E. and R.S. Ayre (1969). The western Sicily earthquake of 1968. National Academy of Engineering Report, National Academy of Science. P.70.

Haines, A. J., A. Jackson, W. E. Holt and D. C. Agnew (1998). Representing distributed deformation by continuous velocity fields, Sci. Rep. 98/5, Inst. of Geol. and Nucl. Sci. (N.Z.).

Haines, A. J. and W. E. Holt (1993). A procedure for obtaining the complete horizontal motions within zones of distributed deformation from the inversion of strain rate data, J. Geophys. Res., 98, 12,057-12,082, doi:10.1029/93JB00892.

Herring, T. A., R. W. King, M. A. Floyd, S. C. McClusky (2015), GAMIT Reference Manual. GPS Analysis at MIT, Mass. Inst. of Technol., Cambridge.

Herring, T. A., M. A. Floyd, R. W. King, S. C. McClusky (2015), GLOBK Reference Manual. Global Kalman filter VLBI and GPS analysis program, Mass. Inst. of Technol., Cambridge.

Holt, W. E. and A. J. Haines (1995). The kinematics of northern South Islands, New Zealand, determined from geologic strain rates, J. Geophys. Res., 100, 17,991-18,010, doi:10.1029/95JB01059.

Jarvis, A., H.I. Reuter, A. Nelson and E. Guevara (2008). Hole-filled SRTM for the globe Version 4. available from the CGIAR-CSI SRTM 9om Database (http://srtm.csi.cgiar.org).

Kreemer, C., W. E. Holt, S. Goes and R. Govers (2000). Active deformation in eastern Indonesia and the Philippines from GPS and seismicity data, J. Geophys. Res., 105(B1), 663-680, doi:10.1029/1999JB900356.

Lavecchia, G., F. Ferrarini, R. de Nardis, F. Visini and S. Barbano (2007). Active thrusting as a possible seismogenic source in Sicily (Southern Italy): some insights from integrated structural-kinematic and seismological data, 
Tectonophysics, 445, 145-167.

Marcelli, L., and G. Pannocchia (1971). Uno studio analitico sui dati ipocentrali di 10 terremoti avvenuti in Sicilia occidentale nel gennaio del 1968, Ann. Geofis, 24, 287-306.

Mattia, M., M. Palano, V. Bruno, F. Cannavò (2009). Crustal motion along the Calabro-Peloritano Arc as imaged by twelve years of measurements on a dense GPS network, Tectonophysics, 476, 528-537.

Mattia, M., V. Bruno, F. Cannavò, M. Palano (2012). Evidences of a contractional pattern along the northern rim of the Hyblean Plateau (Sicily, Italy) from GPS data, Geol. Acta, 10, 12, 63-70.

Michetti, A. M., F. Brunamonte and L. Serva (1995). Paleoseismological Evidence in the Epicentral Area of the January 1968 Eartqhakes, Belice, Southwestern Sicily. in: L. Serva and D. B. Slemmons (eds): "Perspectives in Paleoseismology”, A.E.G. Special Publication, 6, 127-139.

Monaco, C., S. Mazzoli and L. Tortorici (1996). Active thrust tectonics in western Sicily (southern Italy): the 1968 Belice earthquakes sequence, Terra Nova, 8, 372-381.

Palano, M., L. Ferranti, C. Monaco, M. Mattia, M. Aloisi, V. Bruno, F. Cannavò and G. Siligato (2012). GPS velocity and strain fields in Sicily and southern Calabria, Italy: updated geodetic constraints on tectonic block interaction in the central Mediterranean, J. Geophys. Res., 117, B07401.

Pipitone, C., A. Maltese, G. Dardanelli, M. Lo Brutto and G. La Loggia (2018). Monitoring water surface and level of a reservoir using different remote sensing approaches and comparison with dam displacements evaluated via GNSS, Remote Sens., 10, 71.

Pondrelli, S., S. Salimbeni, G. Ekström, A. Morelli, P. Gasperini and G. Vannucci (2006). The Italian CMT dataset from 1977 to the present, Phys. Earth Planet. In., 159, 286-303, doi:10.1016/j.pepi.2006.07.008.

Rigano, R., B. Antichi, L. Arena, R. Azzaro and M.S. Barbano (1999). Sismicità e zonazione sismogenetica in Sicilia occidentale, GNGTS - Atti del $17^{\circ}$ Convegno Nazionale.

Rovida, A., R. Camassi, P. Gasperini and M. Stucchi (2011). CPTI11, The 2011 Version of the Parametric Catalogue of Italian Earthquakes, Milano, Bologna. http://emidius.mi.ingv.it/CPTI 